\title{
Geomagnetic study of the South Atlantic Magnetic Anomaly (SAMA) considering the geology in southern Brazil, northern Argentina, Paraguay and Chile
}

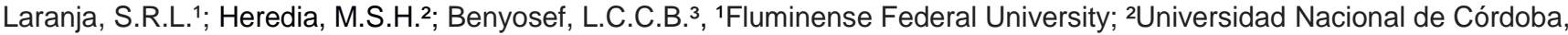 \\ ${ }^{3}$ National Observatory
}

Copyright 2018, SBGf - Sociedade Brasileira de Geofísica

Este texto foi preparado para a apresentação no VIII Simpósio Brasileiro de Geofísica, Salinópolis, 18 a 20 de setembro de 2018. Seu conteúdo foi revisado pelo Comite Técnico do VIII SimBGf, mas não necessariamente representa a opinião da SBGf ou de seus associados. É proibida a reprodução total ou parcial deste material para propósitos comerciais sem prévia autorização da SBGf.

\begin{abstract}
The geomagnetic variations recorded in the south Atlantic region are known to present a lower intensity when compared to elsewhere in the world. This pattern can be attributed to the phenomenon of the South Atlantic Magnetic Anomaly (SAMA), which originates from an inverse magnetic flux at the core mantle boundary beneath South America and South Africa, whose existence is observed in the last 200 years (Gubbins et al., 2006). This study describes the geology of a large strip, from the Atlantic coastal region of southern Brazil to the coastal region of the Pacific of Chile. In this analyzed region the geological formations have many differences between them, which have a different impact on the analysis of the SAMA. This paper relates the displacement of the SAMA from 1918 to 2018, associating it with the regional geologies of each country used in this study. We also attempt to analyze the Solar Quiet $(\mathrm{Sq})$ variations of the geomagnetic components horizontal $(\mathrm{H})$, declination (D) and vertical $(\mathrm{Z})$ of different longitudes using quiet and disturbed days to observe its geological implications.
\end{abstract}

\section{Introduction}

The South Atlantic Ocean is a region of large interest due to its anomalous geomagnetic field, caused by the South Atlantic Magnetic Anomaly (SAMA). In this region the strength of the internal magnetic field is significantly lower when compared to elsewhere in the world. The low geomagnetic field in this region causes a strong increase of radiation due to the distortion of the inner van Allen radiation belt, affecting satellites when passing through the SAMA (Heirtzler et al., 2002). The growth of this reversed flux region may be related to the Earth's magnetic field attempting to reverse (Gubbins, 2008). Although its center is currently located in the Paraguayan territory, its coverage reaches most of South America (continental and oceanic).

The field of the crust is generated by the magnetic content of its rocks, which results in the magnetic field of the earth that can be measured by the secular variation, which we use in this work.

The daily variation of the Earth's magnetic field in geomagnetically quiet conditions, Sq, results from primary electric currents flowing in the ionosphere and along lines of force, and from secondary currents induced in the Earth and oceans (S. R. C. Malin et al., 1976).

We intend to correlate the secular variation and the $\mathrm{Sq}$ current system with the geology of the strip BrazilParaguay-Argentina-Chile (Figure 1), because there is a great difference in the thickness of the crust, by transforming the graphics from time ( $Z$ component) to the frequency domain, for comparison with its depth.

In this work we intend to approach the time evolution of the SAMA as well. An estimative of its evolution, from 1590 to 2005 can be seen in figure 2 .

The data were obtained from the Brazilian and Argentine magnetic observatories, magnetic repeated stations and values taken from the International Geomagnetic Reference Field (IGRF).

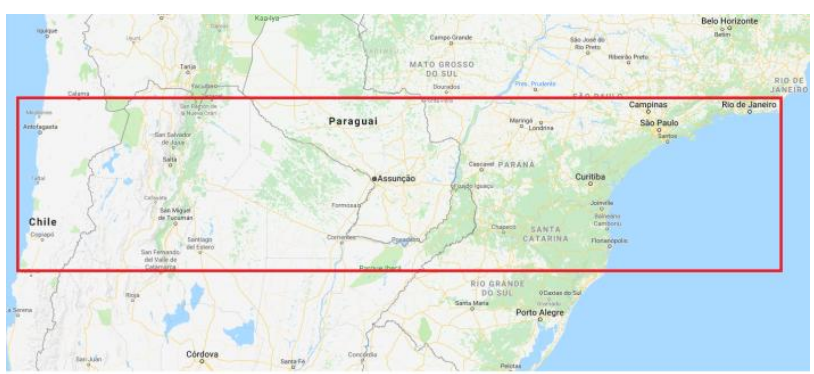

Figure 1. Modified map showing the studied region.
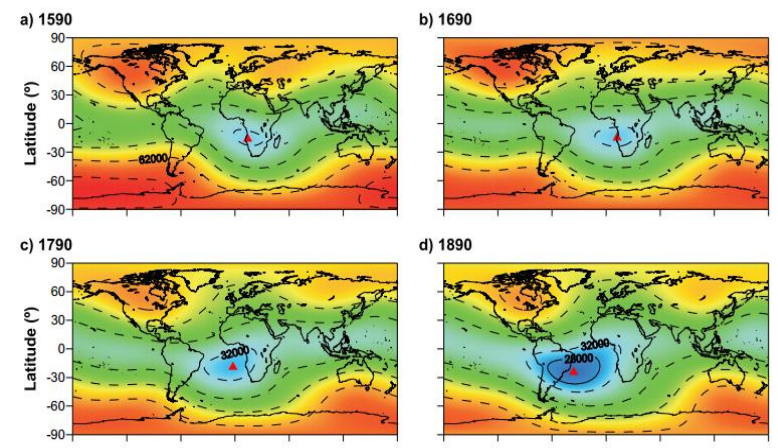

d) 1890
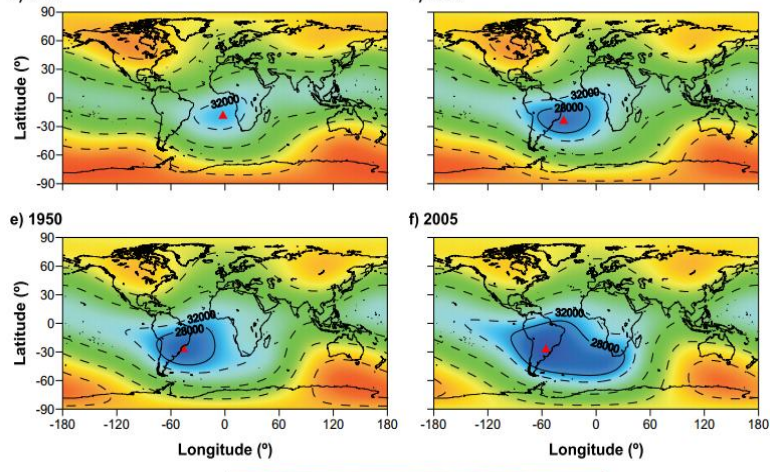

f) 2005

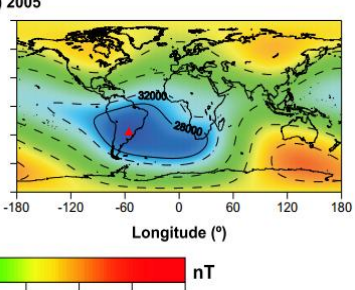

2200030000380004600054000620007000078000

Figure 2. Time evolution of the SAMA from 1590 to 2005, obtained with GUFM1 and IGRF models. (Hartmann et al., 2009). 


\section{Method}

The period used to study the displacement of the SAMA was 1918 to 2018, associating it with the regional geologies of each country used in this study. For the (Sq) variations, we selected months from 2017 for comparison to the seasonal variation of the geomagnetic field. The quiet and disturbed days were chosen according to the planetary magnetic index, $\mathrm{Kp}$ for the quietest one and the Ap index for the disturbed days. The $\mathrm{Kp}$ and $\mathrm{Ap}$ indexes are provided by the International Service of Geomagnetic Indices (ISGI).

The data used has one-minute resolution and one-hour median values were derived. A quiet level baseline was defined for each day as the mean of six nighttime values. $\mathrm{dH}$ and $\mathrm{dZ}$ were computed by subtracting the baseline from $D$ and $Z$ geomagnetic components (Yamazaki, Y.,et al., 2011), according to the equation 1 .

$d D(U T)=D(U T)-\frac{D(0)+D(1)+D(2)+D(22)+D(23)+D(24)}{6}$

After that we compared the behavior of the $Z$ component with the geology of the regions studied, by using the FFT (Fast Fourier Transform) to compare the diurnal variations with the depth of the crust in each region. We made a correlation of the $\mathrm{Z}$ component morphology with how much we believe that the geology can affect the curves obtained.

The Earth's magnetic field is slowly changing on time scales that range from years to millennia. Such changes are referred to as secular variation. Here we compare the vertical component $(Z)$ of the secular variation with the geology of the regions studied in this work.

\section{Geological considerations}

The geological evolution of the State of Paraná began more than 2.8 billion years ago.

Geological records, although discontinuous before 570 million years, are essentially magmatic and metamorphic rocks, which form the basis of the South American continental platform.

This basement, here denominated by the term shield, is exposed in the eastern part of the State (First Plateau and Coastal), being covered to the west by the volcanic and sedimentary cover denominated Basin of the Paraná.

The study of the rocks and fossils of Paraná indicates that its territory was already covered by seas, glaciers, marshes and deserts, as well as immense basaltic volcanism, which gave rise to the Third Paranaense Plateau.

In the coastal lowland, Serra do Mar and First Plateau, there are older magmatic and metamorphic rocks, partially covered by recent sediments of marine and continental origin (Figure 3).

The Second Planalto constitutes the outcropping range of the Paleozoic sediments of the Paraná Basin. Overlapping these sediments occur the volcanic rocks of Mesozoic age of the Serra Geral Group, forming the Third Plateau, covered by Cretaceous sediments in the northwest of the State. Recent sediments occur in all regions, especially in river valleys, in addition to other types of unconsolidated deposits.
In the state of Santa Catarina, the following lithologies emerge from east to west: the recent coastal sediments; a range of older magmatic and metamorphic rocks; the succession of Gondwanian sedimentary rocks; and the basal, intermediate and acid lavas spills of the Serra Geral Formation.

Together with the last rock formation events of the Santa Catarina shield, an essentially depositional regime was established on a stable platform - the South America Platform - that resulted in the covering of all these older rocks by the sediments that constitute today the Gondwanic sequence of the Basin of the Paraná, an outcrop in the central-eastern portion of the State (Figure 4).

This episode of great crustal stability was violently interrupted by the beginning of the separation between South America and Africa, which coincided with the most extensive volcanism that has been reported about a continent and which now represents the coverage of the entire western part of the Santa Catarina state.

Recent studies have demonstrated the great variation in the chemical composition of these rocks, initially considered only as basaltic.

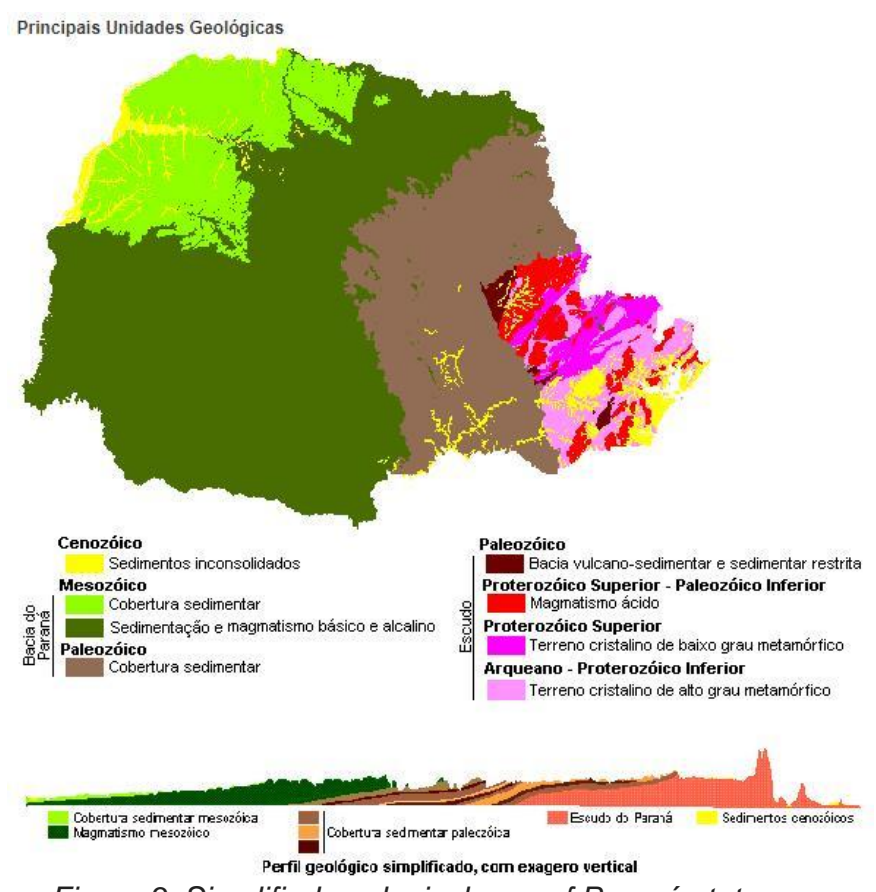

Figure 3. Simplified geological map of Paraná state. 


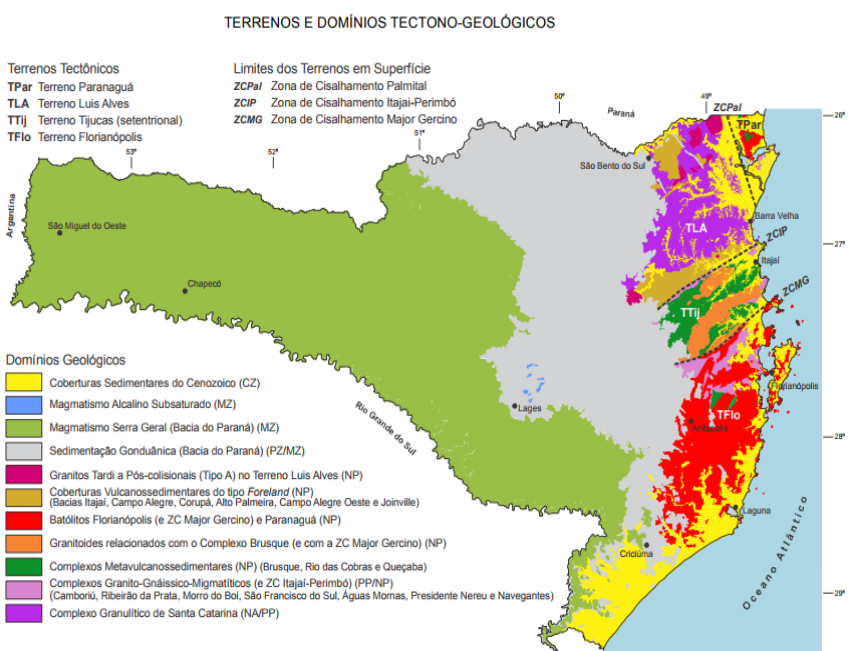

Figure 4. Simplified geological map of Santa Catarina state.

The Paraguayan territory is divided into two major regions, western and eastern, as can be seen in figure 5 . In general, the geotectonic picture of Eastern Paraguay points to the existence of several poles of tectonomagmatic activity, which gave rise to numerous alkaline foci distributed in several provinces;

The Alto Paraguay region contains saturated and unsaturated sienitic rocks and is about $250 \mathrm{Ma}$; those of Amambay and Central are linked to rocks of potassic tendency and exhibit approximate age of $130 \mathrm{Ma}$; the Misiones is related to ultra-alkaline rocks with a mean age of $116 \mathrm{Ma}$, while the most recent one (61-39 Ma) contains several bodies of ultrabasic rocks of a sodium nature. The geological knowledge about the Paraguayan Chaco (Western Paraguay), especially regarding the coverage of more recent unconsolidated sediments, is still very scarce. This is explained by the underdeveloped infrastructure and also by the geological situation; because approximately $80-90 \%$ of the surface consists of quaternary and possibly tertiary sediments, often redeposited, which are covered by more or less dense vegetation. A simplified geological map of Paraguay can be seen in Figure 6.

The analyzed zone corresponding to the Argentine territory, includes the provinces of Misiones (Litoral), Formosa, part of Chaco (Chaco-Paranaense Plain), Jujuy, Salta and Parte de Tucumán (NOA).

In the province of Misiones, the rocks that make up the Paraná basin are evident. These rocks are the product of a regional eruptive event during the Upper Jurassic-Early Cretaceous that covered an area of approximately $1,200,000 \mathrm{~km}^{2}$ occupying part of the territories of Brazil, Argentina, Paraguay and Uruguay. These rocks correspond to the basalts of the Serra Geral formation and cover most of the province of Misiones and extend to the area of Concordia Province of Entre Rios.

The dominant rock is tolelic Basalt (abundance in Fe) which is available in the form of castings, layer reefs and dykes. The flows are usually horizontal and have variable thickness.

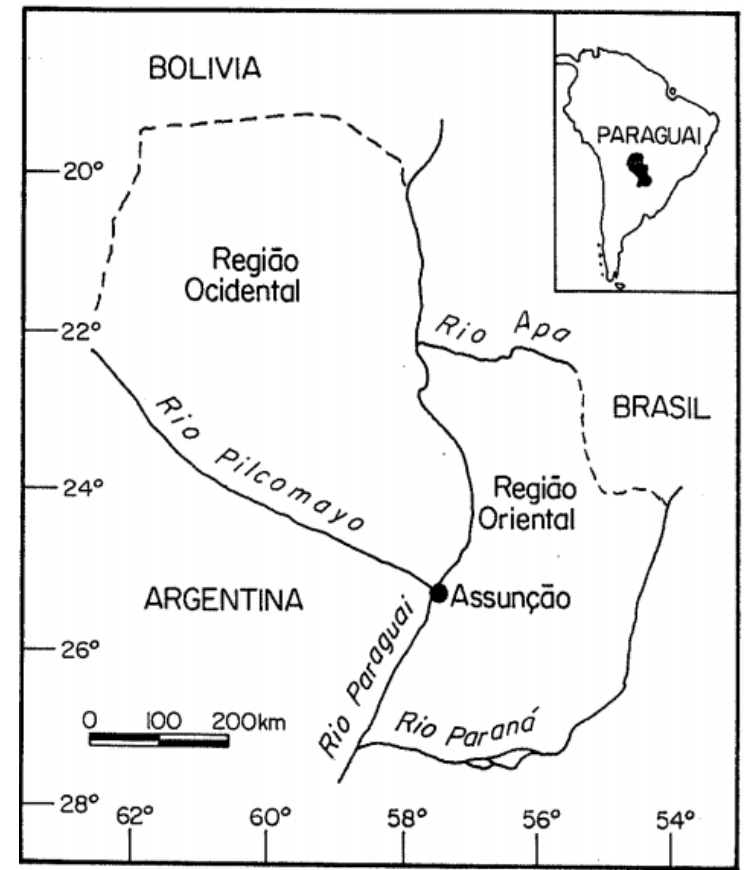

Figure 5. The main division of the Paraguayan territory.
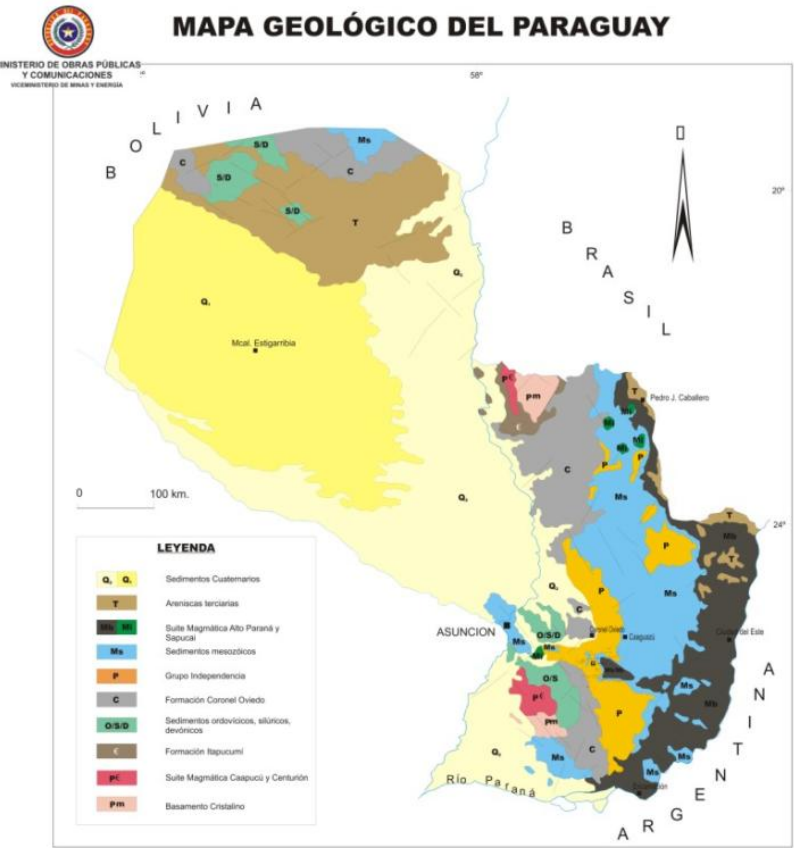

Figure 6. Simplified geological map of Paraguay.

There are also in Misiones, rocks of the Botucatú Formation, which are red, yellowish pink sandstones of very good thickness, well selected that underlie, interspersed and overlap at different levels of the Jurassic-Cretaceous basalt.

They are quartz sands to quartzofeldespáticas of homogeneous granulometry (Figure 7) 


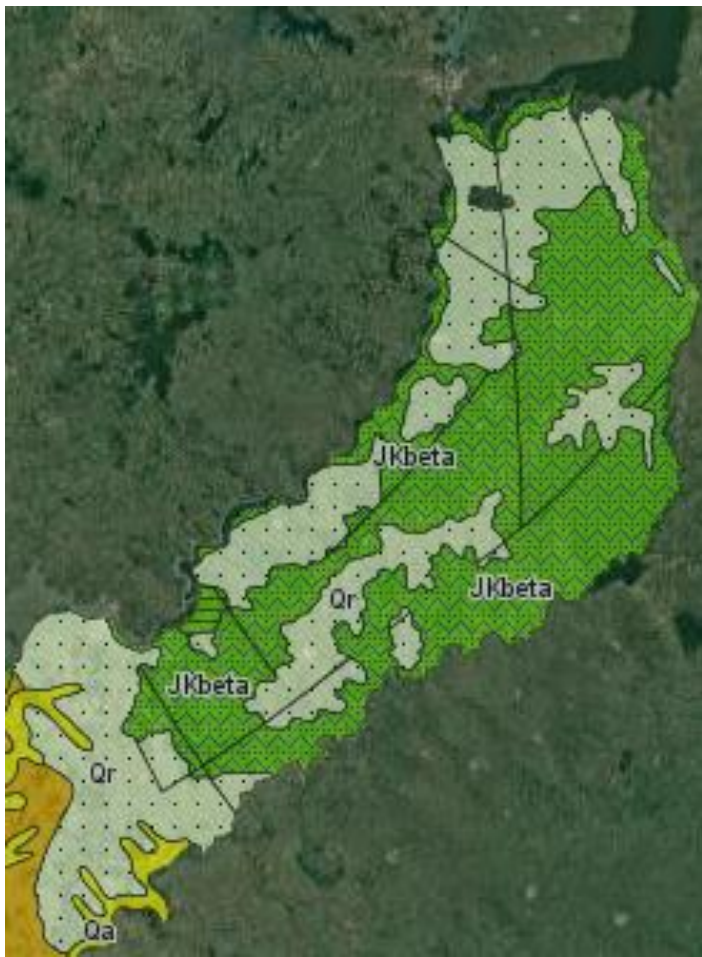

Figure 7. Geological map of Misiones.

The Chaco-Paraense plain has a negative tendency, where in the past sedimentary marine and continental sedimentary series have accumulated. At present, sediments are deposited, mostly from the destruction of mountainous elevations located to the west, carried by wind and rivers. It is considered as a piedmont.

The basement is formed by granitic plutonic rocks and some basic bodies belonging to the Proterozoic. For the Cambrian-Ordovician period in the Mesozoic, continental deposits prevailed, such as final sandstones, quartzites and orthocuarcites, while during the Cenozoic there were periods of marine sedimentation, such as pelites and continental sedimentation periods such as sandstones, siltstones and pellets of the Chaco Formation. The quaternary was affected by the rising of the Andes, causing sedimentation net fluvial continental as silts and sands (Figure 8 ).

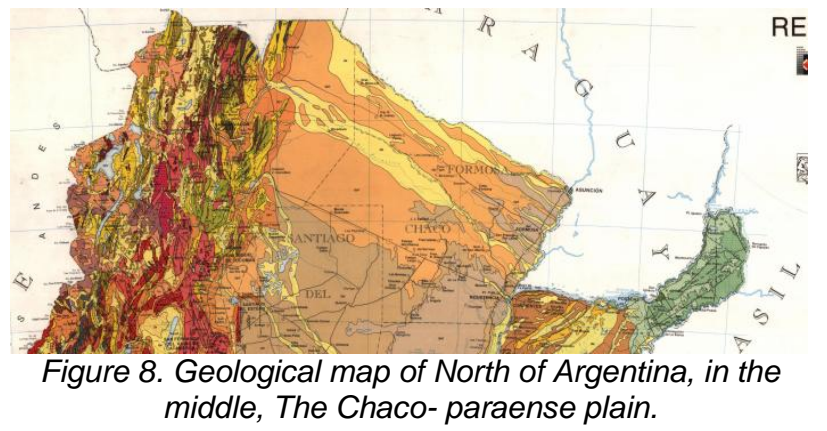

The NOA region is divided into four geological provinces: Puna, Eastern Cordillera, SubAndean Sierras and Santa Barbara System.

The basement of the Region is given by the Puncoviscana Formation (Precambrian) and corresponds to a turbiditic sequence composed of pelitic sediments with incipient metamorphism, metamorphosed, slates, phyllites, quartzites and metagrauvacas.

Next to the basement are the deposit of the Cerro Oscuro Formation (Upper Carboniferous) and the Arizaro Formation (Permian to Lower to Middle), exposed in the western Puna of Argentina. It is interpreted that the Cerro Oscuro Formation accumulated in an alluvial fan system, which later evolved into a fluvial system entangled in gravel to sandy, and that the Arizaro Formation was deposited in a mixed silicoclastic - carbonate platform. The relationship between both units is a conforming discontinuity (Atacama Discordance) and the hiatus coincides with a peak of glaciation that occurred during the Asselian-Sakmarian.

The Mesozoic period was characterized by the Salta Group. It is a powerful predominantly clastic sedimentary complex, to a lesser degree carbonaceous, with low volcanite levels of very localized distribution. They are continental deposits and in a lesser proportion subscacts It is divided into 3 subgroups:

SUBGROUP PIRGUA (reddish sandstones, limestones and conglomerates with a thickness of $450 \mathrm{~m}$ ). SUBGROUP BALBUENA (Calcareous sandstones, oolitic and stromatolitic limestones, marls and pelites, with a thickness of 210 meters) and SUBGRUPO SANTA BÁRBARA (Sandstones, siltstones, clays and loams 600 meters thick).

Finally, the Cenozoic was characterized by clastic deposits such as conglomerates, breccias and sandstones, whereas during the Quaternary, due to the influence of the Andes, the predominant deposits were volcanic deposits, such as breccias, dacites and volcanic tuffs. (Figure 9)

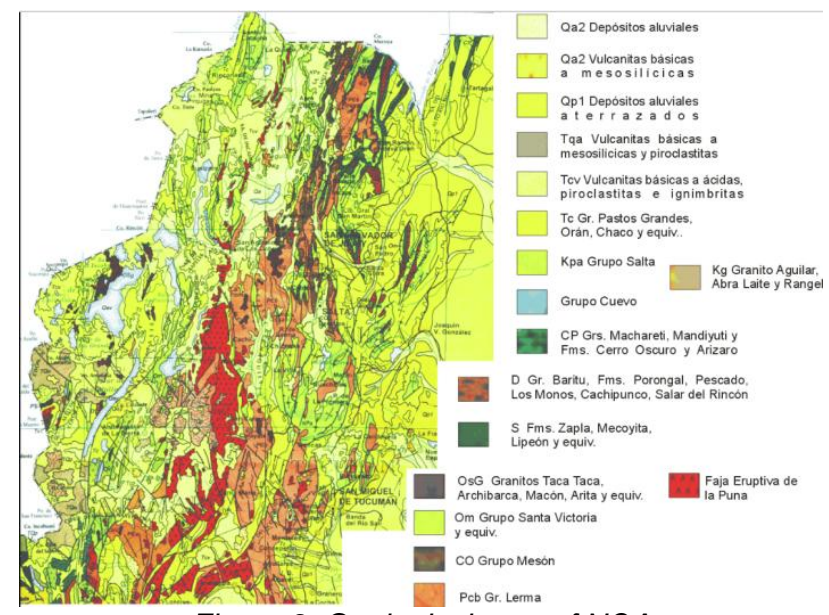

Figure 9. Geological map of NOA 


\section{Results}

Figure 10 shows the total geomagnetic field $(F)$ of seven regions into the studied area. We separated each region with almost the same longitude (but different latitudes) and compared the curves obtained by the IGRF-12 with the SAMA.

All of the graphics shows a decrease of the total field from 1918 to 2018, indicating an approximation of the SAMA anomaly to the South America region. In the studied regions that are located more to the west, the intensity of the total field is currently smaller than in the east, which is the coast of Brazil. This can be explained by the westward drift of the SAMA.

For the past century the SAMA southern displacement can be separated into two intervals. After 1945-1950, the latitude variation was much smaller than that for the previous period 1900-1945. The mean variation rate for the past 60 years was very small, practically without a change in latitude (Hartmann et al., 2009).

Between 1915 and 1940, the SAMA center was approaching VSS, reaching a minimum distance of less than $500 \mathrm{~km}$ (Hartmann et al., 2009). For this period, the intensities for the regions continuously decrease even when the distance of the SAMA center with respect to these areas increases. However, it is important to note that the SAMA area of influence increases, as is evident from the $28000 \mathrm{nT}$ contours on the maps of Figure 2 .

Figure 11 displays all the regions together, showing how much SAMA decreased the geomagnetic field of the southeast part of South America.
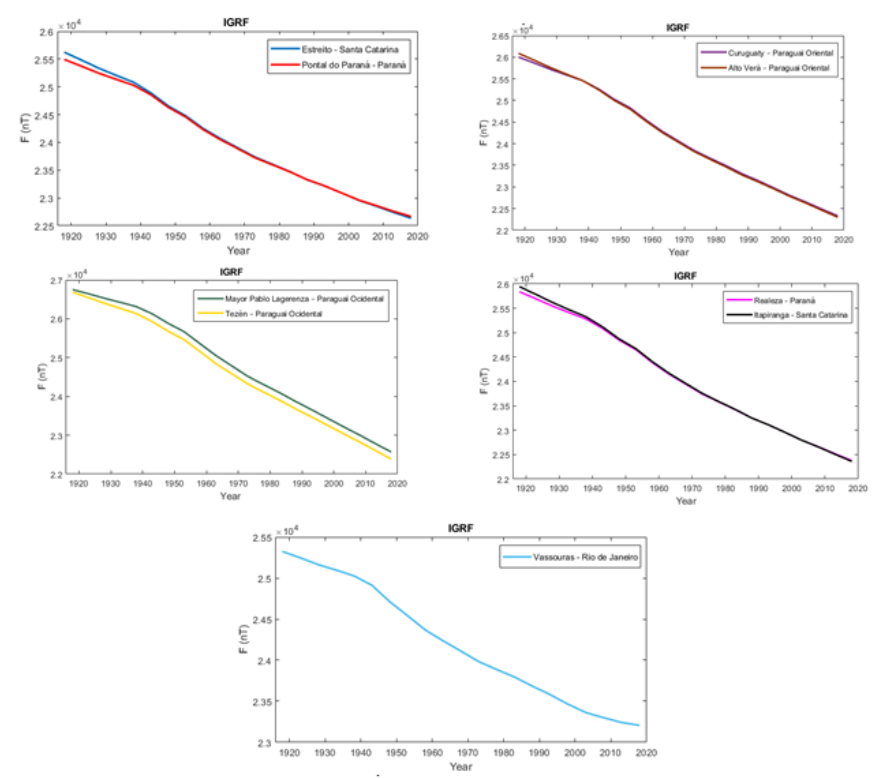

Figure 10. IGRF model for the studied regions, separated by the same longitude.

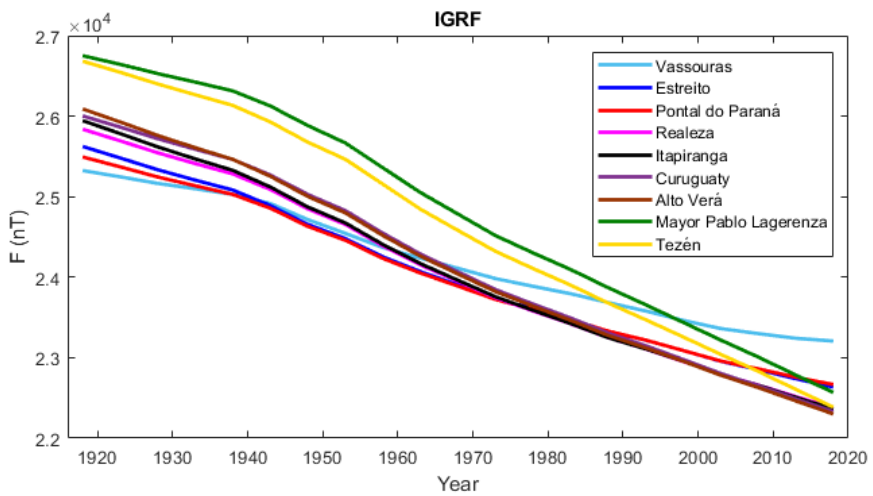

Figure 11. IGRF model for the selected regions.

\section{Conclusions}

The results show how the secular variation would be associated with the geology of these analyzed regions in this preliminary study, particularly due to a great difference in the thickness of the crust over BrazilParaguay-Argentina-Chile strip.

It is apparent that SAMA causes a decrease in the total field intensity when it approaches the observatories and the regions studied.

The main characteristics of the SAMA time and space evolution are a decrease in total geomagnetic field intensity, increase in the influence area and both westward and southward drifts (Hartmann et al., 2009).

The results of this preliminary study confirm that the morphology of the curves obtained to $\mathrm{H}, \mathrm{D}$ and $\mathrm{Z}$ can be related to the SAMA.

Finally, an elaborated model is being prepared to include all those influences.

\section{Acknowledgements}

The authors are thankful to the Observatório Nacional, for the financial support. Also, we thank the INTERMAGNET and REBOM for the data of the diurnal variation used in this work. We also thank the Brazilian Symposium committee for the opportunity.

\section{References}

Spomenko J. Mihajlović, 2012. Geologica Macedonica, Vol. 26, No. 1, pp. 37-51 (2012).

Luiz Fernando Scheibe, A Geologia de Santa Catarina Sinopse Provisória, Geosul - № 91 - 19 sem. 1986.

Ana María Valentina Castillo Clérice, 1986. Reavaliação da Geologia de Paraguai Oriental, Tese de Doutoramento - Universidade de São Paulo, Instituto de Geociências. 
Delio Orué, 1996. Síntese da Geologia do Paraguai Oriental, com ênfase para o magmatismo alcalino associado, dissertação de Mestrado - Universidade de São Paulo, Instituto de Geociências.

Atlas Geografico del Chaco Paraguayo, Informe y 12 Mapas Tematicos. Unidad GIS - REDIEX. Mayo de 2009, Asunción - Paraguay.

Atlas Comentado da Geologia e dos Recursos Minerais do Estado do Paraná, MINEROPAR - Minerais do Paraná SA, Curitiba, 2001.

Gelvam André Hartmann, 2005. A Anomalia Magnética do Atlântico Sul: Causas e Efeitos, Dissertação de Mestrado. Universidade de São Paulo, Instituto de Astronomia, Geofísica e Ciências Atmosféricas Departamento de Geofísica.

Koch and Kuvshinov, Does the South Atlantic Anomaly influence the ionospheric Sq current system? Inferences from analysis. Earth, Planets and Space (2015) 67:10.

Gelvam A. Hartmann and Igor G. Pacca, Time evolution of the South Atlantic Magnetic Anomaly. Anais da Academia Brasileira de Ciências (2009) 81(2): 243-255 (Annals of the Brazilian Academy of Sciences). 